\title{
Actualization of Transformational Leadership based on Spiritual Empowerment for Enhancing Quality of Higher Education
}

\author{
Muhammad Junaidi \\ Asmi Faiqatul Himmah \\ Institut Agama Islam NegeriJember \\ junaidimuhammad858@gmail.com
}

\begin{abstract}
Leadership has significant and strategic role for enhancing the quality of higher education institution. In implementing transformational leadership based on spiritual empowerment, the leadership should have mastered these four components: a) charisma, b) inspirational motivation, c) intellectual stimulation, d) individualized consideration. This article uses descriptive qualitative approach and gets some discoveries as follows; first, IAIN actualyzes the concept of "Islam Nusantara" in constructing academic atmosphere. Second, IAIN actualyzes KH. Shiddiq's four pillars of spiritual empowerment. Research result showed that the implementation of transformational leadership style has been implemented as follows: First, to fulfill and explore charismatic leadership in IAIN, the principal implemented some steps as follows: First, illustrating vision and mission formulation clearly. Second, foster pride in the institution. Third, respected and appreciated by followers. Forth, needs to gain the support and trust from followers. Second, to express his inspirational motivation to his followers, the principal implemented his ability in communicating high expectation and exploring the symbols/jargon/motto of institution for focusing on the effort to explore them simply. Third, the way principal stimulates his followers intellectual through these following things: 1) promoting intellectual behavior. 2) conducting learning organization. 3) Intellectual sensitivity. Fourth, able to provide appropriate solutions. 4)Individualized Consideration.
\end{abstract}

Keywords: Transformational Leadership, spiritual empowerment, the quality of higher education 


\section{INTRODUCTION}

Transformational leadership is a far more complex process, the realization of which requires visionary and inspiring figures. Lewis asserted that the goal of a transformational leader is to transform people and organizations: change minds and hearts; enlarge vision, insight, and understanding; clarify purposes; make behavior congruent with beliefs, principles, and values; and bring about changes that are permanent, self-perpetuating, and momentum building. In 1995 Avolio and Basscategorized transformational leadership skills as the four as follows; Idealized influence, inspirational motivation, intellectual stimulation, and individualized consideration (Bass, 1998: 26). This will be unless in meaning without supported by spiritual empowerment.

James MacGregor Burns (1978) conceptualized transformational leadership as those who stimulate and inspire followers to both achieve extraordinary outcomes, in the process, develop their own capacity of ledership and sometimes move ollowers to exceed expected perormance, as well as lead to high level offollowers' satisaction and commitment to the group of organization. (bass, 1998). It has several components as follows; first, idealized influence(charisma). This is about the leader having a clear set of values and demonstrating them in every action then providing a role model or their followers. Second, inspirational motivation. This means that leader has a clear vision which can be articulated to followers in helping their experience to get the same passion and motivation or reaching the goals. Third, intellectual stimulation. Transformational leadersstimulatetheir followers' effortsto be innovativeand creativeby questioning assumptions, reframing problems, and approaching old situation in new ways, then Creativity is encouraged. (Bass and Riggio, 2006: 7).

Fourth, individualized consideration. The leader attends to each follower's needs, acts as a mentor or coach to the followers. This also encompasses the need to respect and celebrate the follower's contribution to the team. Transformational leaderspayspecial attention toeach individual follower's needs for achievementandgrowth by acting as a coach or mentor.(Towns, 1997: 193).

On the other hand, scholars found that transformational leadership is at least ascommon and useful in the public sector (Dumdum, Lowe, \&Avolio, 2002; Wright \&Pandey,2009). The term 
of Transformational Leadership was first presented by Downton(1973), followed byBurns (1978), who focused on transformational and transactional leadership at the political level. Since the early 1980s, transformational leadership has become one of the most popular styles of leadership and has attracted researchers' attention.

Moreover, transormational leadership is seen to be sensitive to organization building. Developing shared vision, distributing leadership and building institution culture necessary to current restructuring trade in the institution. Its meaning describes that transormational leadership takes human educational recourses that have been led for growing sensitive guidance and improvement organization, improvement of vision totally, the distribution fo leadership authority, and developing school organization which can be necessity on the higher education. The term "transormation" has been defined as " a change or refinement in the consciousness and character of individual human beings (Bush and Folger in Jossey Bass 1999).

According to (Bass, 1985) TL has categorised by four behaviours named the "Four I's" as described below:

First, Idealized Influence; 1) Known as charismatic, 2) leaders behave shows as being a role model to the employees, 3) Leaders are admired, trusted and respected, 4) Followers want to emulate and imitate leaders, 5) Leaders are perceived by their employees as having extraordinary abilities and skills, 6) Leaders are willing to take risks and do the right thing, which indicates high standards of moral and ethical behavior, 7) Leaders make individual sacrifices for others' interest and benefit.

Second, Intellectual Stimulation; 1) Leaders encourage followers to participate, being active, accept challenge to complete the mission, 2) Leaders encourage their followers to be creative and innovative in trying new approach instead of old situations. Followers involved in the process of addressing problems and identifying solutions, 3) Leaders thoughtful suggestions and create an atmosphere that gives meaning to the followers and increases feelings of self-confidence, 4) Stimulating followers to look at problems from different sides, 5) Rethinking about new ideas which have never been investigated and examined before.

Third, Inspirational Motivation; 1) Leaders motivate and inspire followers to achieve their work. 2) Focus on team spirit and express 
confidence that goals will be achieved, 3) Leaders demonstrate conditions of enthusiasm and optimism about the future, 4) Leaders demonstrate the shared vision and organisation goals. 5) Leaders meet followers' expectations and needs.

Fourth, Individualized Consideration; 1) Supportive climate, create new learning opportunities, recognise individual differences in needs and desires, encourage two-way exchange in communication, and manage followers by walking around, 2) A leader listens efficiently and tries to develop followers continuously. In return, followers give feedback on their performance, 3) Leaders support success and achievement by providing resources, allowing followers to take responsibility. 4) Followers feel more involved in problem-solving, being a part of the organisation.

To supportthe transormational leadership, spiritual empowerment has significant role to implement. Spirituality at workplace is a new topic in organizational psychology. Spirituality workplace is related to a construction that indicates an enhancement of quality performance. The results indicated that there were two factors forming the spiritual climate in the workplace, namely vision and mission that motivated the employees and made them connected with their purposes at work, and the second factor was employees' deep concern of their lives (Yogatama, Volume 42, No. 1, April 2015)

Spirituality is not something new in human experience. In all big religious tradition, for certain level, support contemplation life, where looking for meaning and objective are principal things that harmony in life with other people is very important. (Ashmos and Duchon, 2003) moreover, in workplace, as Widyarini (2011) stated that spirituality has signiicant role or civic virtue.Civic virtue is one of dimension for organizational citizenship behavior from five dimensions which was ever proposed by Organ (2006); altruism, courtesy, sportsmanship, civic virtue, and consciousness. Civic virtue shows how far someone contributed for organizational decision responsibly which correlated with spiritual leadership, openhabitual organization and climate of spiritual workplace. Absolutely this will support or enhance the quality of the organization. There are seven forms of spiritual empowerment as Seth Barnes (2010) stated as follows: first,vision. Second, guidance Third, spiritual gifts. 
Fourth, anointing.Fifth, weakness. Sixth, authority. Seventh, identity.

The questions appearing to return For this, how to implement spiritual empowerement in higher education especially for State Institute of Islamic Studies of Jember (IAIN)? The answer is "there are two main steps being chosen by IAIN Jember under decision of transormational leadership as Follows: First, implementing Islam Nusantara as the vision. Islam Nusantara being understood asmodel of thought, comprehension, and implementation of Islamic teachings covered by culture and tradition developed in Southeast Asia (the scope of which is limited to Indonesia), that reflects Islamic identity with methodological nuance. The identity has various and controversial responses when it is socialized among Moslem because Islam is one, namely, Islam taught by Prophet Muhammad. Otherwise, the majority of Islamic scholars accepted Islam Nusantara. That Islam is one which is substantively true, but it expressed widely including Islam Nusantara. Islam is presented (thought, comprehended, and implemented) through cultural approach. The result leads to the thinking model, comprehending, and implementing Islamic teachings which are harmonious, comprehending, and implementing Islamic teachings which are harmonious, Islamic thought which is caused by local culture, especially Javanese culture, or called cultural acculturation. Islam in indonesiacan be a role model. It brings peaceful and harmonious messages, so it could be socialized internationally and replaced misleading opinion that Islam is full of violence.(Qomar, Vol.17 No.2 Tahun 2015)

There are some terms of Islam Nusantara being defined by some experts of islam. The concept of Islam Nusantara (IN) observedfrom the structural theory of Islam and local culture relation, along with the reason whyIN is developed into the concept of the Islamic proselytizing "Rahmatanlil'alamin" by theintellectual ofNahdhatulUlama (NU). It comes from the NU Intellectual's claim that IN is themediator in the controversy of Islam and local culture relation, moreover in the global scaleit is going to be proselytized in the International, whereas the IN is still regarded as an issueand has not fulfilled the knowledge standard yet. Through philosophical approach, sociolinguistics based on the data in www.nu.or.id and topic analysis as its data analysis,it is found that the intellectual of NU used eight approaches to concept the IN. The IN setthat Islam 
influences Indonesian culture and the IN's success and ability to dialogue withIndonesian culture trigger the intellectual $\mathrm{NU}$ to promote it to the International. (Luthfi,Vol. 1, Nomor 1, Januari-Juni 2016).

Second, implementing four principles of $\mathrm{KH}$. Akhmad Shiddiq'sconsisting: shalat berjamaah, reading Al-quran, reading shalawat, and not to be despotic to our selves and other people. According to the transision of IAIN to be university, the name of KH.Akhmad Shiddiq will be named in the university. One of the steps taken byBabun along with a number of officials, on Thursday evening(5/16/2019) he visited the house of $\mathrm{KH}$ Muhammad BalyaFirjounBarlaman, son of $\mathrm{KH}$ Ahmad Siddiq. In a closed meeting for the media, it was known that Babun intended to ask for permission to use the name of $\mathrm{KH}$. Ahmad Siddiq as the new name of UIN Jember.

"We deliberately permit to the family of Kiai Ahmad Siddiq, to ask for his sinceritythat the name of $\mathrm{KH}$ Ahmad Siddiqwillbe used as name for UIN Jember," Babun said when confirmed by reporters at IAIN Campus, Friday (05/17/2019).

According toBabun statement, the hard selection of the name of KH Ahmad Shiddiq as the name of UIN Jember, is appropriate choice as the legend "He is a great figure, and his contribution to the nation's establishment, especially for IAIN history," he added. Babun told, the process of the establishment of IAIN Jember could not be separated from significant role (contribution) of KH Ahmad Siddiq with KH Dhofier Salam,and a number of other figures. "At his initiative, who wanted an Islamic campus in Jember, finally IAIN was born. President Soekarno had ever said"never forget to the history"he said. In addition, he continued, many proposals entered the campus, either through text messages or delivered directly, so that if IAIN Jember changed its status to UIN Jember, then it would be better to use the name $\mathrm{KH}$ Ahmad Siddiq, as a national figure who also co-founded this campus."So (this consideration), because many people have come to me, to use the name $\mathrm{KH}$ Ahmad Siddiq as the name of UIN Jember. "For this reason, I ask my family to ask permission, so that we make his name as the name of UIN Jember," he concluded (https://faktualnews.co/2019/05/17/iain-jember-jadi-uin-bakalgunakan-nama-kh-ahmad-siddiq/140817/). That is why the name of KH. Ahmad Shiddiq chosen as the name of UIN Jember. 
In education, quality almost becomes goal. Crosby (1979) defines quality as "conformance to requiremnet". While Juran and Gryna (1988) define quality as "fitness or use". Deming (1986) defined quality as predicable degree of uniformity and dependability with a quality standard suited to the customer.

A good quality education is one that provides all learners with capabilities they require to become economically productive, develop sustainable livelihoods, contribute to peaceful and democratic societies and enhance individual well-being. The learning outcomes that are required vary according to context but at the end of the basic education cycle must include threshold levels of literacy and numeracy, basic scientific knowledge and life skills including awareness and prevention of disease. Capacity development to improve the quality of teachers and other education stakeholders is crucial throughout this process. ( https://www.vvob.org/en/education/our-vision-on-qualityeducation)

There are five conceptions of quality (Harvey and Green, 1993; Harvey 2007) as follows: first, Quality as exceptional: quality is exclusive, unique, distinctive, self-evident (not necessary to prove), quality is achieved when (implicit) standards are surpassed. Second, Quality as perfection or consistency: quality is exclusive, processfocused and based on speciications being met perectly, and characterised by notions of "no faults: (zero defects) and getting the things right first time.third Quality as fitness or purposuality is inclusive, measured against the objective or purpose, hence focus on efectiveness (either perspective of the service provider or those at the "receiving end": students, employers). Fourth, Quality as value for money: quality is value-based, with a focus on eficiency: quality explicitly being connected to accountability. Fifth, Quality as transfomation: a focus on qualitative value added change (enhancement, empowerement) and improvement, but dificult to measure against predetermined benchmarks or standards.

\section{METHOD}

This research uses qualitative approach because this is often used by researchers in designing grounded theory that includes in the discussion of grounded research ( Bogdan, R.C., and Biklen , 1995: 6) Qualitative research is one of research that products descriptive data from somebody and attitude that can be observed 
(Moleong, 2002: 103) Approach being used is oriented to theory resource about transformational leadership and education quality, and data being got in the location of research with improving field concepts. Kind of this research is using descriptive-qualitative case study. Location of the research can point where the research will be done. The location of this research is in State Institute of Islamic Studies of Jember which is located in Mangli Jember. Data resource is devided in to two sides: primary data collection and secondary data collection. The most suitable primary data collection methodology depends on what kind of information is sought. A research is defined as qualitative if "the purpose of the study is primarily to describe a situation, phenomenon, problem or event and if analysis is done to establish the variation in the situation, phenomenon or problem, without quantifying it. Secondary data is data being described by nobody following experience in the direct phenomenon time. Secondary data in this research is useful as comparer instrument to support data in the field. Secondary data is got from documentation study to written recourse, photos in the research location and another document out of research location Data for this studywere generated from a variety of sources: interview, observation, anddocument review. Data AnalysisTechnique being used is Qualitative Data analysis

\section{FINDING AND RESULT}

As representative in actualyzing transormational leadership style in State Institute of Islamic Studies of Jember, Prof. Babun Soeharto (as interview being done to some lectures) has implemented some strategies (according to scheme of transormational leadership components, as follows:

First, Idealized inluence; His good physical appearance supports his charisma as leader, his networking and collegues in ceantero of Indonesia (moreover being the chief of association of PTKIN) supports his charisma as leader, smart in negociation supports his charisma as leader, the way he communicates, inner beauty, and confidence supports his charisma as leader, the way he increases valence of efort, accomplishment expectancies, instills faith in a better future, creates personal commitment supports as leader.

Second, Inspirational motivation; has a clear vision to bring State Institute of Islamic Studies of Jember as the center of Islam 
Nusantara studies, able to help the followers' experience to the same passion and motivation to reach goal, challenging followers with high standards of expectation by communicating optimism about future goal, exploring symbols for focusing the efort to explore the significance of them in detail.

Third, Intellectual stimulation; recommends lecturers to take post doctoral program in the abroad or Indonesia, Supporting $\mathrm{S}_{3}$ lecturers to finish their study by giving financial reward, Growing academic atmosphere by appreciating scientific research with available reward, Recruiting new productive and innovative youth lecturers to enhance the quality of higher education, Stimulating lecturers to write books to publish, Promoting intelligent behavior, Building learning organization.

Fourth, Individualized consideration; Promoting some talented lecturers for graduated post doctoral degree to be professors, Supporting lecturers to get better study in post doctoral program, Not to distinguish social status both civil servant and others in conducting comfortable work for reaching the goal, Treating many followers or colleagues individually.

As the configuration of implementing spiritual empowerement in State Institute of Islamic Studies of Jember, some concerete steps being actualyzed;

a) Developing the central studies for Islam Nusantara: first, Understanding term of Islam Nusantara as the result of dialogue between text of syariah with reality and local wisdom. (Muhajir in Sahal and Aziz, 2015: 67), second, Understanding term of Islam Nusantara as particular islam base indonesia, integrating the values of teology of islam with the values of local wisdom, and indonesia tradision (Bizawie in Sahal and Aziz, 2015: 239), third, Put it into curricum distributing in every subject of study

b) Implementing KH. Ahmad Shiddiq principle:

* Implementing shalat jamaah on time

* Reading holy quran

* Reading sholawat for prophet Muhammad SAW

* Not to hurt another person

Enhancement of quality on higher education (State Institute of Islamic Studies of Jember) requires specific strategies, as follows (Guerbadit and Duche, 2013: 40): 
1. Implementation of religious education to foster morals and noble character; conceptualized in KKNI curriculum integrated by the imlementation of islam nusantara values and for principles of $\mathrm{KH}$. Ahmad shidding in practice

2. The development and implementation of the competency based curriculum; Implemeting periodical discussion being conducted by LPM of State Institute of Islamic Studies of Jember

3. The teaching and learning process which is interactive and educational; This can be analyzed from the note of supervisors when supervising in the class

4. The inforcement of the national education system by educational evaluation, accreditation and certification; Delegating them to follow workshop, instructing them to write on national or international jornal, books, etc

5. The provision of quality educational facilities; Some units of educational facilities; UPB, LP2M, rumah jurnal etc which support the enhancement of teacher's or student's quality

6. The provision of educational funding based on principles equality and equity; Supporting lecturers who take academic of post doctoral, who wrote $\mathrm{i}$ international journal etc

7. The provision of open education and equality in education; Prefaces of rector in every meeting agenda

8. The implementation of compulsory basic education; Supporting lecturers to always be good learner for enhancing good quality

9. The implementation of autonomous management of education; Making decision of manegerial organization based on local wisdom of State Institute of Islamic Studies of Jember conducted by education demand

10. The empowerement of community roles

11. The central of community empowerement and development

12. The implementation of monitoring activities in national education system; The activities and roles of SPI of State Institute of Islamic Studies of Jember. 
Hence as the consequences of enhancing the quality of higher education, State Institute of Islamic Studies of Jember must consider these following ten characteristics of efective schools (Oecd, 1989) to implement as follows: first, A commitment to clearly and commonly identitied norms and goals. Second, Collaborative planning, shared decision-making, and collegial work in frame of experimentation and evaluation. Third, Positive leadership in initiating and maintaining improvement. Fourth, Staf stability. Fifth, A strategy for continuing sta development related to each school's pedagogical and organizational need. Sixth, Working to a carefully planned and co-ordinate curriculum that ensures suicient place or each student to acquire essential knowledge and skills. Seventh, A high level of parental involvement and support. Eighth, The pursuit and recognition of school-wide values rather than individual ones. Nineth, Maximum in use of learning time. Tenth, The active and subtantial support of the responsible higher education authority.

\section{DISCUSSION}

The actualization of transformational leadership style based on spiritual empowerement in IAIN, chronogically considers the philosophy of strategic role of Mr. Babun Soeharto to transform the existence of STAIN to IAIN as follows:

\section{Transformation from STAIN - IAINJember}

After goingthrough a long process of proposing a transisional process of status from STAIN Jember to IAIN as formulated by the Taskforce Team that was formed by the Chair of STAIN Jember (at that time), finally in 2014, based on Presidential Decree (Keppres) No. 142 of 2014 there had been in Peru $\neg$ STAIN Jemberdeclarated as IAIN Jember. Then followed up with the Regulation of the Minister of Religion of the Republic of Indonesia Number 6, 2015 concerning the Organization and Work Procedure of the State Islamic Institute of Jember.

As the transformation towards IAIN Jember opened many study programs, this was intended to be able to meet the needs of the wider community. Meanwhile, the existing faculties and study programs are as follows:

1. Fakultas Tarbiyah \& Ilmu Keguruan, Program Studi : 

a. Pendidikan Agama Islam (PAI)
b. Pendidikan Bahasa Arab (PBA)
c. Manajemen Pendidikan Islam (MPI)
d. Pendidikan Guru Madrasah Ibtidaiyah (PGMI).
e. Pendidikan Guru Radhatul Athfal (PGRA)
f. Tadris Ilmu Pengetahuan Sosial (IPS)
g. Tadris Ilmu Pengetahuan Alam (IPA)
h. Tadris Bahasa Inggris
i. Tadris Matematika
j. Tadris Biologi

2. Fakultas Syariah, Program Studi:
a. Al-Ahwal al-Syakhsiyyah/AS (Hukum Keluarga/Perdata Islam)
b. Mu'amalah (Hukum Ekonomi Syari'ah)
c. Hukum Tata Negara (Siyasah)
d. Hukum Pidana Islam

3. Fakultas Ekonomi dan Bisnis Islam
a. Perbankan Syari'ah
b. Ekonomi Syari'ah
c. Akuntansi Syari'ah
d. Zakat dan Wakaf

4. Fakultas Dakwah, Program Studi:
a. Komunikasi dan Penyiaran Islam (KPI)
b. Pengembangan Masyarakat Islam (PMI)
c. Bimbingan dan Konseling Islam (BKI)
d. Manajemen Dakwah
e. Psikologi Islam

5. Fakultas Ushuluddin, Adab dan Humaniora
a. Ilmu Al-Qur'an dan Tafsir
b. Ilmu Hadist
c. Bahasa dan Sastra AraB
d. Sejarah dan Kebudayaan Islam

(data recourse: http://www.iain-jember.ac.id/page/detail/sejarahiain-jember) 
Vision and mission of IAIN was determined. This is as an effort to provide direction, motivation and certainty of the ideals to be realized at a certain time. The vision and mission are important to unite the perceptions, views, ideals, hopes and dreams of all parties directly involved in the development of IAIN Jember.

Vision of IAINJember;

Becoming a Center for the Study and Development of Islamic Archipelago

The Mission of IAIN Jember;

a Carrying out superior and competent Islamic, Social and Humanities Sciences.

b Conducting Research to develop Islamic-based Islamic Aspect

c Providing Community Empowerment by relying on Islamic boarding schools-based Islam to improve the quality of life.

$\mathrm{d}$ Institutional development by strengthening domestic and foreign cooperation

From the existence of STAIN to IAIN, many changes having been transformed by the leadership. Those appear from the actualization of transormational leadership to bring IAIN to be better higher education quality. By implementing the main basic principles of trasormational leadership totally such as idealized inluence, inspirational motivation, intellectual stimulation, and individualized consideration which actualized by spiritual empoerement, will take the quality of higher education in IAIN Jember to be better and better

\section{CONCLUSION}

a) Transormational leadership style being actualized by Prof Babun Soeharto as leader of IAIN Jember implemented with considering components of it such as as idealized inluence, inspirational motivation, intellectual stimulation, and individualized consideration to construct the eectiveness $o$ organizational institution

b) Actualization of spiritual empowerement in IAIN Jember used the implementation of Islam Nusantara and also the basic principles of KH. Akhmad Shiddiq; shalat jamaah, reading Al-quran, reading shalawat, and not to despotic to our self and others 
c) Both of item a and $b$ aim to enhance the quality of higher education in IAIN Jember

\section{BIBLIOGRAPHY}

Bass, B., Transformational Leadership: Industry, Military, and Educational Impact. (Mahwah, NJ: Erlbaum Associates, 1998

Bass and Riggio, 2006, transformational leadership, 1. Erlbaum Associates

Towns, 1972, america'sfaster sgrowing church, termessee: impact books

Burns, 1979, leadership, harper and row

Bogdan, R.C., and Biklen, S.K., Qualitative Research For Education: An Introduction To Theory And Methods. (Needham Heights, MA: Allyn Bacon, 1995)

Moleong, Lexy, Qualitative Research Method, Bandung: Rosdakarya, 2002

Moleong, Lexy, Qualitative Research Method, Bandung: Rosdakarya, 2002

Yin, R. K. Case study research: Design and methods. (Newbury Park, CA: Sage Publications, 1989)

Sukmadinata, N.S., Education Research Method, Bandung: PT RemajaRosdakarya, 2007

Sugiono, Quantitative and Qualitative and $R \mathcal{E} D$ Research Method, Bandung: CV. Alfabeta: 2008 